\title{
FEASIBILITY OF RICE HUSK FOR ELECTRICITY GENERATION: A CASE STUDY AT AVNASH RICE MILL
}

\author{
*1Kumih, F., ${ }^{2}$ Issahaku, M. \\ ${ }^{I}$ School of Engineering, University for Development Studies, Tamale, Ghana \\ ${ }^{2}$ Energy Technology Centre, School of Engineering, University for Development Studies, Tamale, Ghana \\ *Corresponding author's email: kumihfelix1996@gmail.com
}

\begin{abstract}
The erratic power supply from the national grid has the potential to decrease the production hours of industries. Climate change is altering rainfall patterns and threatening crop production and food security. Rice factories' process capacity is affected negatively. The Hybrid Optimization for Multiple Energy Resources (HOMER) software used in the study provided the technical and economic modeling to provide power for a rice mill in northern Ghana. A biomass system is considered the optimal system comprising a $1250 \mathrm{~kW}$ biogas generator, with a gasification ratio of 0.4, an estimated daily rice husk generation of 50 tonnes/day, and a daily load demand $3689.75 \mathrm{kWh} /$ day. The cost of energy (COE) of the proposed system was US\$0.0703/kWh, with a total net present cost (NPC) of \$712,082.00 and initial capital of US\$437,500.00. The base system which was a $1300 \mathrm{~kW}$ diesel generator, with NPC of US\$2.93M, COE of US\$ 0.290/kWh, and lower initial investment capital of US\$186,697.00. The proposed system could generate electricity in a $98,158 \mathrm{kWh} / \mathrm{yr}$ surplus, which could power the mill's administrative building with zero unmet loads. Analysis of the system showed that the quantity of rice husk produced at the Avnash mill was sufficient for power generation from a biogas generator at current production. It suggested that the mill could be self-sufficient and contribute significantly to reducing GHG emissions.
\end{abstract}

\section{Keywords: Rice husk, Hybrid system, Sensitivity, Electricity, COE, HOMER}

\section{Introduction}

According to the International Energy Outlook (IEO), global industrial energy consumption would reach about 315 quadrillion British thermal units (Btu) by 2050 (EIA, 2019). The primary sources of energy for both domestic and industries are heavily dependent on fossil fuels. Fossil fuel reserves are depleting more than they can be replenished, threatening its sustainability. The negative impact of fossil fuels threaten life on the planet, necessitating exploring alternate sources of energy. Renewable energy sources present an alternative to satisfy the global energy demands due to a worldwide diminution in fossil fuel reserves over the past years from the need for energy and its related services to meet demands; social and economic development, welfare, and health, which is on the increase (Sarkodie \& Owusu, 2016).

As targeted by goal 7 of the Sustainable Development Goals (SDGs), energy development provides clean and affordable energy for all. A country's ability to meet its energy demands for residential and commercial purposes directly links to the economy's growth. Studies show that energy supply deficiency, power cuts, and load shedding 
are significant challenges in most developing countries due to the increasing population and increased energy demands (Sarkodie \& Owusu, 2016). It has challenged stakeholders to explore renewable energy sources. Biomass gasifiers have been tried in some countries to supplement conventional electricity generation sources. An example of two companies, Husk Power Systems (HPS) and Decentralized Energy Systems India (DESI), successfully generated electricity from rice husks in India (IRENA, 2012a). In China and South East Asia, rice husks power plants have commercially been installed.

In Ghana, load shedding "dumsor" as known in local slang due to generating capacity shortage from rising fuel prices, has revived interest in renewable energy and demand-side energy management (Acheampong et al., 2019). Therefore, the government and stakeholders have made a lot of effort in increasing renewable energy performance to variegate the electricity sources. Among such actions is introducing the National Energy Strategy of 2010; one of the objectives was to accomplish universal electrification by 2020 . To obtain the targets, Acheampong et al. (2019) suggested that available renewable energy resources should be mobilized and harnessed for electricity generation to achieve the Sustainable Development Goal (SDG 7) targets.

According to Acheampong et al. (2019), there is a growing need for new energy innovation. Furthermore, the country must consider using decentralized renewable energy systems to reduce pressure on the national grid. This study, therefore, performed the techno-economic analysis of the energy potential of rice husk biomass for electricity generation purposes for a rice mill through simulation by Hybrid Optimization of Multiple Energy Resources (HOMER).

Biomass is an organic matter available renewable through photosynthesis by plants to store the sun's energy. When consumed, the plant's stored energy is transferred to other organisms (Twidell \& Tony, 2015). Biomass includes feedstock obtained from animals or plants, such as wood and agricultural produce, and organic waste from municipal and industrial sources. The energy generated from biomass can produce heat, electricity, and transportation fuels (OECD/IEA \& FAO, 2017).

Biomass could be used as input fuel for electricity generation through available technologies to sustain the rice mill's activities. One type of biomass suitable for this purpose (electricity generation) is the rice husks biomass, as confirmed by Hossain et al. (2018). Many studies have described the use of rice husks for electricity generation processes as environmentally friendly. According to Yadav et al. (2015), it is amicable because the grown biomass absorbs carbon dioxide $\left(\mathrm{CO}_{2}\right)$ during photosynthesis. An essential consideration for rice husk as an efficient energy source is its energy content, calculated by (AmeOko et al, 2018; Mhilu, 2014; Obaidulla et al, 2016), as almost $15 \mathrm{MJ} / \mathrm{kg}$. Therefore, they can efficiently be utilized to meet rice mills' heat and electricity demand through various conversion technologies.

The rice husk is also called the rice hull. The coating on a seed or grain of rice is formed from hard materials, including silica and lignin, to protect the seed. It can be used to produce solid fuel (i.e., briquettes and pellets), carbonized rice husk produced after burning, and rice husk ash after combustion. Also, it could be used for energy production in its loose form. The various elemental components of rice husk make it desirable to be used as feedstock for electricity generation.

However, these values have been calculated differently in different studies. According to Mohiuddin et al. (2016), rice husk contains Oxygen $42.55 \%$, Nitrogen $0.28 \%$, Sulphur 0.55 , Hydrogen $5.51 \%$, and Carbon $36.74 \%$. But other studies put the composition as Carbon is $37.05 \%$, Hydrogen, $8.80 \%$, Nitrogen, $0.25 \%$, Sulphur $0.50 \%$, and Oxygen $35.03 \%$. Abedin \& Das (2014) also calculated the composition as: Oxygen $31 \%-37 \%$, Nitrogen $0.23 \%-0.32 \%$, Sulphur $0.04 \%-0.08 \%$, 
Hydrogen $4 \%-5 \%$, and Carbon $35 \%$. According to Quispe et al. (2016), rice variety, type of fertilizer used, soil chemistry, etc. account for variations in composition values. The organic matter (cellulose and lignin) and mineral components (silica, alkalis, and trace elements) make it a valuable energy source.

Unfortunately, the rice husk gasification system has not been commercialized in Ghana. However, some time ago, researchers from the Technical University of Denmark and the University of Lisbon investigated the potential of providing electricity to the country's un-electrified rural communities using rice husk gasification mini-grids (ETA-Florence, 2015). The hybrid system of rice husk feasibility studies with Solar PV and conventional diesel for electricity generation for a rural village of Bangladesh without parity to the national grid suggested cost-effectiveness than the use of diesel generator (Islam et al., 2018).

The share of modern renewable energy in global final energy consumption has seen a slight increase from the 2010 figure, which hovered around a threshold of about 10\% (Sue Retka Schill, 2013). It was observed that while modern renewables utilization is increasing, there is also an increase in energy demand. In the Planned Energy Scenario, the share of modern renewable energy in the final energy supply would increase to $17 \%$ by 2030 and $25 \%$ by 2050 . In the Transforming Energy Scenario, this share would increase to $28 \%$ by 2030 and $66 \%$ by 2050 . Therefore, the percentage would need to increase six-fold compared to today and two-and-a-half times compared to the Planned Energy Scenario (IRENA, 2020a). Biomass renewable energy reduces greenhouse gas (GHG) emissions because it is considered a carbon-neutral bearer when produced and used on a sustainable basis (IRENA, 2014).. According to UNEP (2008), 140 billion tonnes of biomass waste is obtained globally every year, and that it is of high value when it comes to material and energy recovery. It is evident then that biomass is readily available in a considerable amount to use as feedstock for electricity generation. The quality of biomass feedstock is affected by moisture content, ash content, particle size, and density (IRENA, 2012b). Although the literature review has given a fair knowledge on the global use of biomass for energy yet it needs to fulfill the following criteria to be accepted as a sustainable energy resource;

- It should be readily available.

- It should generate zero waste and have a reduced impact on the environment.

- Biomass energy generation should not affect arable land for food resources.

\section{Material and Methods Study area}

Avnash rice mill is a paddy processing plant located at Changnayili in the Tolon District, situated on latitude 9.403811 , longitude -0.951177 along the main road from Tamale to Nyankpala (see figure 1). The fully automated mill of Buhler, has a total processing capacity of 500 metric tons per day. It is the largest in Africa and can convert about $70 \%$ of the paddy rice into full-grain but underutilized. The plant acquires paddy from local farmer households; it sources from some 13,860 farmer households at full capacity utilization. This consequently creates more jobs while providing the country with adequate local rice. Avnash company's branded rice product, called royal farmers, comes in two types: parboiled rice and white rice. Although the plant has 500 metric tonnes per day capacity, it does not run for a full day. It currently runs 8 hours a day (8:00 am -5:00 pm) with a breaking period between 1:00 pm and 2:00 pm. The researchers estimate that the plant processes 31.5 tonnes of paddy per hour. Therefore, the milling capacity has dropped to 250 tonnes per day instead of 500 tonnes per day. The plant is underutilized because of reduced hours of production. This is due to erratic power supplies by the national grid and the high diesel cost for running the $1250 \mathrm{~kW}$ diesel generator on site 


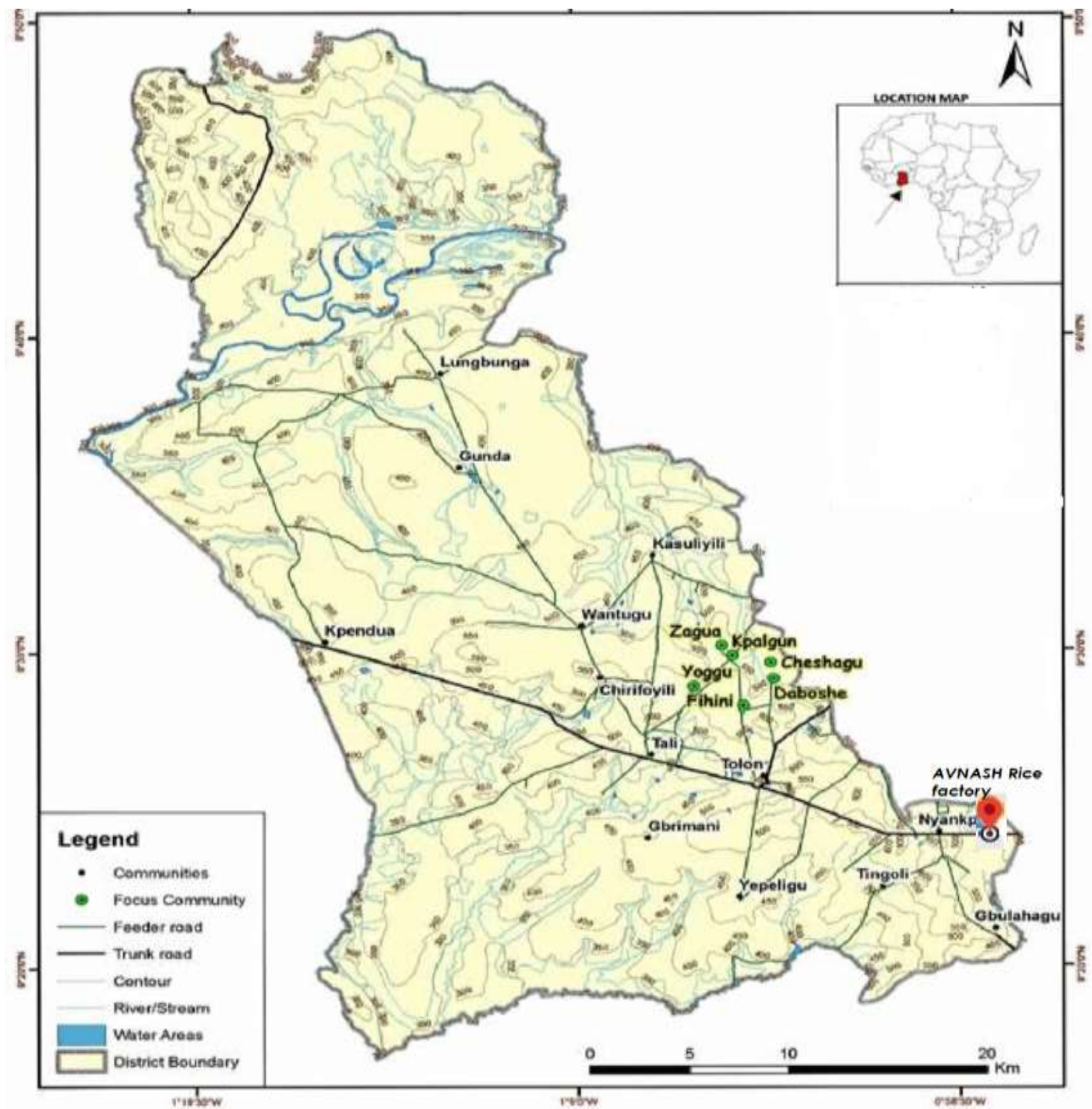

Figure 1: Map of Tolon District Showing Avnash Rice Factory Adopted

Source: (Boafo et al., 2016)

HOMER's simulation is meant to reduce the uncertainties associated with loads demands, input variables, and renewable energy sources. It is fulfilled through three (3) main tasks: simulation, optimization, and sensitivity analysis. Firstly, it figures out whether the system is feasible and its net present cost. It takes into account the possibility of the system to sufficiently feed the load. Secondly, multiple simulations performed on different system configurations. It estimates the system's lifecycle cost, total installation cost, and the operating system's cost in its entire life. The optimal system configuration is the one that fulfills the user-specified challenges as the lowest Total Net Present Cost (TNPC). Finally, HOMER evaluates the effect of the resource through several optimizations under given assumptions. The study considers cost 
associated with the currently used diesel generator compared to the proposed biomass generator.

\section{Resource Assessment}

Resource assessment was done to estimate the quantity of rice husk generated at the mill. It identifies the amount and availability of rice husk as feedstock to generate electricity. Knowing the quantity of husk available helped to estimate the amount of energy the system can produce. The following relation by Ahlgren (2008) estimates the amount of rice husk produced per hour. The researchers estimated that the plant processes 31.5 tonnes of rice paddy per day all year round. The company did not provide rice paddy processed in the mill to show the seasonal variation due to the company's confidentiality policy. An assumption of husk to paddy ratio of 0.2 was taken, and using Ahlgen (2008) estimates, rice husk of the mill was calculated as;

Hprod $=$ PRprod $\times$ HPR $\times$ H Avlt

Where:

Hprod $=$ RH production (tons/hr),

PRprod $=$ Paddy rice processed $($ tons $/ h)$

$H P R=$ Husk to Paddy Ratio (0.2),

$H$ Avlt $=$ Husk availability (100\%).

Hprod $=31.5 \times 0.2 \times 1=6.3$ tons $/ \mathrm{h}(6300$ $\mathrm{kg} / \mathrm{h})$.

Hence, the plant produced 6.3 tonnes of rice husk per hour.

Considering the eight hours of plant operation, the total husk generated per day calculated as $8 \times 6.3 \approx 50$. Therefore, 50 tonnes of rice husk is generated by the plant per day except for weekends.

\section{Rice husk to biogas}

The biomass generator does not consume rice husk directly. The husk is converted to either syngas or biogas, depending on the technology used. The literature review specifies that the gasification of rice husk produces syngas, while anaerobic digestion generates biogas. Each of the gas produced has its advantages and disadvantages. But

Kumih et al., 2021: UDSIJD Vol 8(2) according to Solarte-Toro (2019), the costs of producing electricity via anaerobic digestion is relatively higher than the gasification method. It was outside the scope of this study to generate biogas/syngas from rice husks. Therefore, the researcher assumed a gasification ratio of 0.4 for simulation purposes based on literature. It is the ratio of biogas produced to the amount of biomass feedstock consumed in the gasifier. It implies that, for any amount of rice husk consumed in the gasifier, $40 \%$ will produce syngas. The gasification ratio depends directly on the equivalence ratio (ER). The equivalence ratio is the ratio of actual air-fuel used in gasification to the stoichiometric air-fuel for combustion. A stoichiometric ratio is the ideal ratio of air-fuel that will burn all fuel without excess air. The improvement upon the quality of gas produced, the equivalence ratio, is the most crucial parameter to consider (Salaudeen, 2018). The lower the carbon content of the feedstock, the higher the equivalence ratio.

Additionally, the higher the equivalence ratio, the better the gasification and gas produced. According to Kirsanovs et al. (2016), a gasification ratio of $0.2-0.4$ is suitable for biomass gasification.

\section{Load Profile estimation}

A good load estimation is significant for designing the system size to meet the mill's electricity demands adequately. The equipment considered includes the Husker, De-stoner, Polisher, Paddy separator, Graders, and Air compressors. The administrative building and the security lightning were not part of the load profile. The total load was calculated to be $645 \mathrm{~kW}$ in Table 1. The equipment consumed energy from 8:00 GMT to 17:00 GMT and operated within that period. An assumption that power consumption was constant for every hour. At 13:00 GMT, the plant shuts off completely hence zero power consumption. The equipment considered under the milling 
section were: husker, de-stoner, polisher, paddy separator, grader, air compressor.

Table 1 shows the wattage and quantity of equipment in the milling section used in load

Table 1: Energy Consumption of

\section{Equipment}

\begin{tabular}{lllll}
\hline Equipment & Watts & Quantity & $\begin{array}{l}\text { Total } \\
\text { Power } \\
(\mathbf{k W})\end{array}$ & $\begin{array}{l}\text { Energy } \\
(\mathbf{k W h})\end{array}$ \\
\hline Husker & 28.75 & 4 & 115 & 115 \\
\hline De-stoner & 19.5 & 4 & 78 & 78 \\
\hline Polisher & 41.25 & 8 & 330 & 330 \\
\hline $\begin{array}{l}\text { Paddy } \\
\text { separator }\end{array}$ & 4 & 2 & 8 & 8 \\
\hline Graders & 0.5 & 8 & 4 & 4 \\
\hline $\begin{array}{l}\text { Air } \\
\text { compressor }\end{array}$ & 55 & 2 & 110 & 110 \\
\hline TOTAL & & & & $\mathbf{6 4 5}$ \\
\hline
\end{tabular}

Source: Authors Construct

\section{System Components Costing}

The HOMER software finds the optimal system configuration by considering the system with the least total Net Present Value (NPV). The study did not consider the investment required to gasify the rice husk used in the biomass generator. The simulation compares it to different configurations' economics for the simulation, all economic calculations done in US dollar terms. Different functions are used by HOMER to calculate the annualized cost, levelized cost of electricity and the net present cost. Equation (1), (2), and (3) show cost and energy functions used to derive an optimized renewable energy model.

$\mathrm{NPC}=\sum_{t=1}^{T}\left(C_{O \& M}+C_{c-} C_{s a l}+\left(C_{r e p} *\right.\right.$ N) (1)

Where,

$C_{c}=$ initial capital cost invested at the start of the project

$C_{O \& M}=$ annual operating and maintenance cost of the system

$C_{\text {sal }}=$ life salvage value of components at the end project

Kumih et al., 2021: UDSIJD Vol 8(2) profiling. Figure 2 also illustrates the estimated daily load profile of the milling section of the plant.

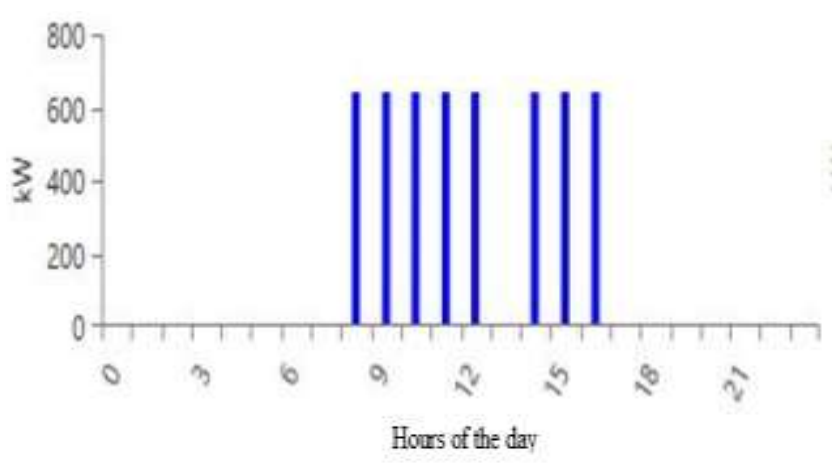

Figure 2: Estimated Daily Load Profile of Mill Source: Authors Construct

$C_{\text {rep }}=$ cost required for replacement of components in the system

$N=$ number of replacements in the project lifetime

$T=$ lifetime of the project in years

$E_{\text {sys }}=\left(\left(P_{\text {sys }}-P_{\text {loss })} * T_{\text {sys }}\right)\right)$

Where,

$E_{s y s}=$ energy used by the consumer $(k W h)$

$P_{\text {sys }}=$ total Power generated by the system ( $k W h)$

$P_{\text {loss }}=$ power used by the system itself or losses $(\mathrm{kW})$

$T_{\text {sys }}=$ time for which the system generates power throughout project life $(h)$

$\mathrm{COE}=\frac{\left(\left(P_{\text {sys }}-P_{\text {loss }} * T_{\text {sys }}\right)\right)}{\mathrm{NPC}}$

Where,

$C O E=$ cost of electricity

$N P C=$ total net present cost of system

\section{Economic Inputs}

The average inflation rate and nominal discount rate values used in the simulation were $9.4 \%$ (GSS, 2020) and 20\%, respectively. The Avnash rice mill has a vast land. Therefore, the land cost was not factored into the simulation. In HOMER, the

DOI: https://doi.org.10.47740/609.UDSIJD6i 
system fixed capital cost is the capital cost of the system regardless of the size. Other economic parameters required by the HOMER software are;

- Initial Capital Cost: The cost incurred to install a component at the start of a project.

- Initial Replacement Cost: The money paid to replace the system.

- Initial O\&M Cost (kWh): The cost to operate and maintain a component of a system.

- System Fixed Capital Cost: The capital cost at the beginning of project irrespective of the size of the system.

- System Fixed O\&M Cost: The repetitive annual cost irrespective of system size or architecture.
- The average price of biomass feedstock: The per tonne cost of biomass feedstock is free. The carbon content of $33.94 \%$ is used from literature(Wang et al., 2016).

In decommissioning and installing new or faulty parts, a cost is incurred and must be considered in total cost of replacement. The researchers assumed the replacement cost to be the same as the initial equipment costs, similar to a previous study. Furthermore, a linear cost curve is taken for the components' size, the component's prices, and vice versa (Mubarick et al., 2020). Table 3 presents the cost estimates used in the simulation.

Table 3: Cost Estimates

\begin{tabular}{llllll}
\hline Components & Size & $\begin{array}{l}\text { Initial } \\
\text { capital } \\
\text { Cost } \\
\text { (US\$) }\end{array}$ & $\begin{array}{l}\text { Replacement } \\
\text { cost } \\
\text { (US\$) }\end{array}$ & $\begin{array}{l}\text { Initial } \\
\text { O\&M } \\
\text { cost } \\
\text { (US\$) }\end{array}$ & $\begin{array}{l}\text { Fuel price } \\
\text { (US\$) }\end{array}$ \\
\hline $\begin{array}{l}\text { Generic Biogas } \\
\text { Genset }\end{array}$ & $1 \mathrm{MW}$ & $350,000.00$ & $350,000.00$ & 1.0 & 0 \\
\hline $\begin{array}{l}\text { Generic Fixed } \\
\text { Capacity }\end{array}$ & $500 \mathrm{~kW}$ & $143,613.00$ & $143,613.00$ & 0.06 & $\begin{array}{l}0.844 \text { (Global Petrol } \\
\text { Prices, 2020) }\end{array}$ \\
\hline
\end{tabular}

Source: Authors Construct

\section{Sensitivity inputs}

Sensitivity variables allow the modeler to analyse the system's behaviours when there is a variation in system parameters. The varying price of diesel fuel, inflation, discount rate, and rice husk availability were the sensitivity variables for the study. At full capacity, the mill would produce approximately 100 tonnes of rice husk per day. The maximum operating capacity of the mill was used as a sensitive case to generate maximum rice husk. A $10 \%$ multiplier was used on fuel prices and system component prices. These variable variations intend to determine the impact on the cost of energy (COE) and feasibility. Table 4 shows the sensitivity variables used in the simulation. 
Table 4: Sensitivity Inputs

\begin{tabular}{|c|c|c|c|c|c|c|}
\hline $\begin{array}{l}\text { Biomass } \\
\text { gasification } \\
\text { ratio } \\
(\mathbf{k g} / \mathbf{k g})\end{array}$ & $\begin{array}{l}\text { Biomass } \\
\text { scale } \\
\text { average } \\
\text { (tonnes/day) }\end{array}$ & $\begin{array}{l}\text { Diesel } \\
\text { fuel } \\
\text { price } \\
(\$ / L)\end{array}$ & $\begin{array}{l}\text { Bio } \\
\text { capital } \\
\text { generator } \\
\text { cost } \\
\text { multiplier } \\
(*)\end{array}$ & $\begin{array}{l}\text { Bio } \\
\text { replacement } \\
\text { cost } \\
\text { multiplier } \\
(*)\end{array}$ & $\begin{array}{l}\text { Expected } \\
\text { inflation } \\
\%\end{array}$ & $\begin{array}{l}\text { Nominal } \\
\text { discount } \\
\%\end{array}$ \\
\hline 0.4 & 50 & 0.844 & 1 & 1 & 11 & 25 \\
\hline 0.55 & 100 & 0.928 & 1.1 & 1.1 & 9.4 & 20 \\
\hline 0.2 & 25 & 1.00 & 1.2 & 1.2 & 13 & 30 \\
\hline
\end{tabular}

Source: Authors Construct

\section{Simulation Results and Analysis}

Three system configurations were considered feasible for the mill load after the simulation. These systems were a biomass generator, a hybrid of biomass and diesel generator, and a conventional diesel generator system. The schematic diagram for the simulation is shown in Figure 3. The optimal design to meet the load was the biomass generator system at the cost of energy (COE) of US\$ 0.0703 with 50 tonnes/day rice husk generation at a $44 \%$ gasification ratio. The system comprises a $1250 \mathrm{~kW}$ biomass generator, net present cost (NPC) of US\$ 712,082.00. It had the least operating cost and highest initial capital as expected compared to the diesel generator system. The results suggest that the rice husk generated currently at 50 tonnes/day is adequate to generate electricity for the load demand as the average daily consumption of biomass generator is 21.6 tonnes/day. Surplus rice husk generated could still be used as fuel for heat generation in the parboiling of paddy. The results based on the assumption that, gasification technology investment has been made by the mill, there would be variation in economic parameters when gasification investment cost is added to the system. Table 5 illustrates the comparison of the optimized three systems considered.

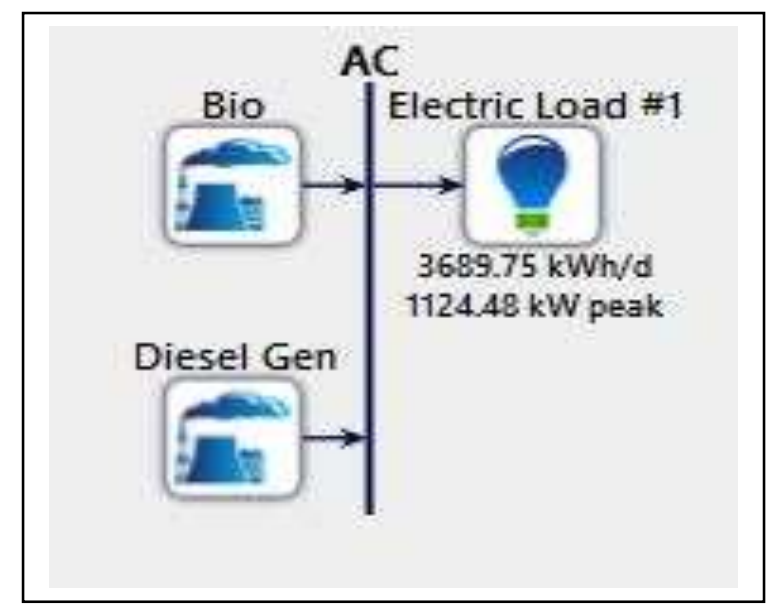

Figure 5: Schematic Diagram of the Simulated System

Source: Authors Construct 
Table 5. Comparison of the Three Optimized Systems

\section{System Configurations}

\begin{tabular}{|c|c|c|c|c|c|}
\hline $\mathbf{S} / \mathbf{N}$ & Description & Parameter & $\begin{array}{l}\text { Biomass } \\
\text { generator }\end{array}$ & $\begin{array}{l}\text { Hybrid } \\
\text { (Biomass \& } \\
\text { Diesel Gen) }\end{array}$ & $\begin{array}{l}\text { Diesel } \\
\text { Generator }\end{array}$ \\
\hline \multirow[t]{2}{*}{1} & \multirow{2}{*}{$\begin{array}{c}\text { System } \\
\text { Architecture }\end{array}$} & Biomass generator $(\mathrm{kW})$ & 1250 & 1250 & - \\
\hline & & Diesel Gen Set $(\mathrm{kW})$ & - & 1300 & 1300 \\
\hline \multirow[t]{4}{*}{2} & \multirow[t]{4}{*}{ Cost Summary } & $\begin{array}{l}\text { Cost of Energy (COE) } \\
\text { (US\$) }\end{array}$ & 0.0703 & 0.0884 & 0.290 \\
\hline & & Net Present Cost (US\$) & $712,082.00$ & $815,296.00$ & $2.93 \mathrm{M}$ \\
\hline & & Operating Cost (US\$) & $36,506.00$ & $36,042.00$ & $365,378.00$ \\
\hline & & Initial Capital (US\$) & $437,500.00$ & $624,197.00$ & $186,697.00$ \\
\hline \multirow[t]{5}{*}{3} & \multirow{5}{*}{$\begin{array}{c}\text { Compare } \\
\text { economics with DG } \\
\text { as the base case } \\
\text { system }\end{array}$} & Present Worth (US\$) & $2,222,856.00$ & $2,039,642.00$ & - \\
\hline & & Annual worth (US\$/y) & $295,528.00$ & $271,170.00$ & - \\
\hline & & Return on Investment (\%) & 126.1 & 72.1 & - \\
\hline & & $\begin{array}{l}\text { Internal Rate of Return } \\
(\%)\end{array}$ & 134.0 & 76.7 & - \\
\hline & & Simple Payback (year) & 0.75 & 1.31 & - \\
\hline \multirow[t]{6}{*}{4} & \multirow[t]{6}{*}{ Electrical } & $\begin{array}{l}\text { Biomass generator } \\
(\mathrm{kWh} / \mathrm{yr})\end{array}$ & $1,444,918$ & $1,442,318$ & - \\
\hline & & $\mathrm{DG}(\mathrm{kWh} / \mathrm{y})$ & - & 2600 & $1,347,652$ \\
\hline & & $\begin{array}{l}\text { Excess Electricity } \\
(\mathrm{kWh} / \mathrm{y})\end{array}$ & 98,158 & 98,158 & 892 \\
\hline & & Unmet load (kWh/y) & 0 & 0 & 0 \\
\hline & & $\begin{array}{l}\text { Capacity shortage ( } \\
\mathrm{kWh} / \mathrm{y})\end{array}$ & 409 & 0 & 0 \\
\hline & & Renewable Percentage & 100 & 99.8 & 0 \\
\hline \multirow[t]{6}{*}{5} & \multirow[t]{6}{*}{ Emission (kWh/yr) } & Carbon Dioxide & 10,587 & 12,709 & 998,351 \\
\hline & & Carbon Monoxide & 15.8 & 29.2 & 6,293 \\
\hline & & Unburnt Hydrocarbons & 0 & 0.589 & 275 \\
\hline & & Particulate matter & 0 & 5.24 & 38.1 \\
\hline & & Sulfur Dioxide & 0 & 5.24 & 2,445 \\
\hline & & Nitrogen Oxides & 9.85 & 22.25 & 5,912 \\
\hline \multirow[t]{3}{*}{7} & \multirow[t]{3}{*}{ Fuel Summary } & Total fuel Consumed & 7877 tonnes & 7864 tonnes & $381,397 \mathrm{~L}$ \\
\hline & & $\begin{array}{l}\text { Average Fuel per day } \\
\text { (/day) }\end{array}$ & 21.6 tonnes & 21.5 tonnes & $1,045 \mathrm{~L}$ \\
\hline & & $\begin{array}{l}\text { Average Fuel per hour } \\
(/ \mathrm{h})\end{array}$ & 0.899 tonnes & 0.898 tonnes & $43.5 \quad \mathrm{~L}$ \\
\hline
\end{tabular}

\section{Source: Authors Construct}

Furthermore, the hybrid system does not significantly use the diesel generator in the optimized design as rice husk is adequate to generate electricity for the current operating

Kumih et al., 2021: UDSIJD Vol 8(2) hours. The DG would augment the deficit of electricity from the 50 tonnes/day of rice husk. It explains why there are the same values for 
both standalone biomass generator and the hybrid system fuel summary information.

\section{Emissions}

Greenhouse gas emissions are of growing concern about the use of fossil fuels. Fossil fuel energy conversion systems usually have the least initial capital cost, making it attractive for investment with little consideration of operating and environmental impact. The simulation confirms high quantities of GHG compared to the biomass generator in Table 5. Continual use of DG to meet the rice milling industry's energy needs even threatens rice processing sustainability. Rice production heavily depends on adequate rains at the right time. Climate change that could directly be linked to greenhouse emissions threatens rainfall patterns resulting in floods and droughts. The quantification of emissions from industries is necessary to develop appropriate policies to keep temperatures within the $1.5^{\circ} \mathrm{C}$ climate goal (IRENA, 2020b).

\section{Sensitivity Analysis}

The sensitivity analysis was employed in the study to determine the behavior of the system under the uncertainty of different parameters of the optimal system. Table 4 lists the sensitivity inputs for various parameters. In the sensitivity analysis, the impact of price variability in diesel, nominal discount rate, inflation rate, increased rice husk generated and gasification ratio on cost of energy and total net present cost were considered. As these parameters increased or decreased, researchers observed that there was a corresponding variation in NPC and COE of the system under consideration. Figure 6 to 10 illustrates the sensitivity on COE and TNPC of the system.

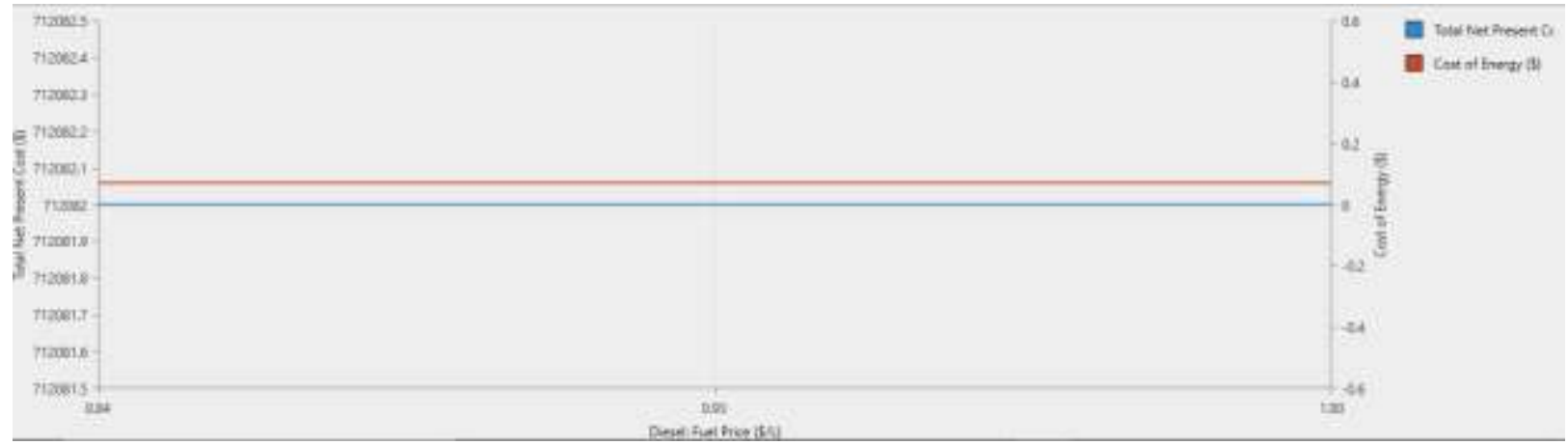

Figure 6: Variation of Diesel Fuel Price on COE and TNPC

Source: Authors Construct

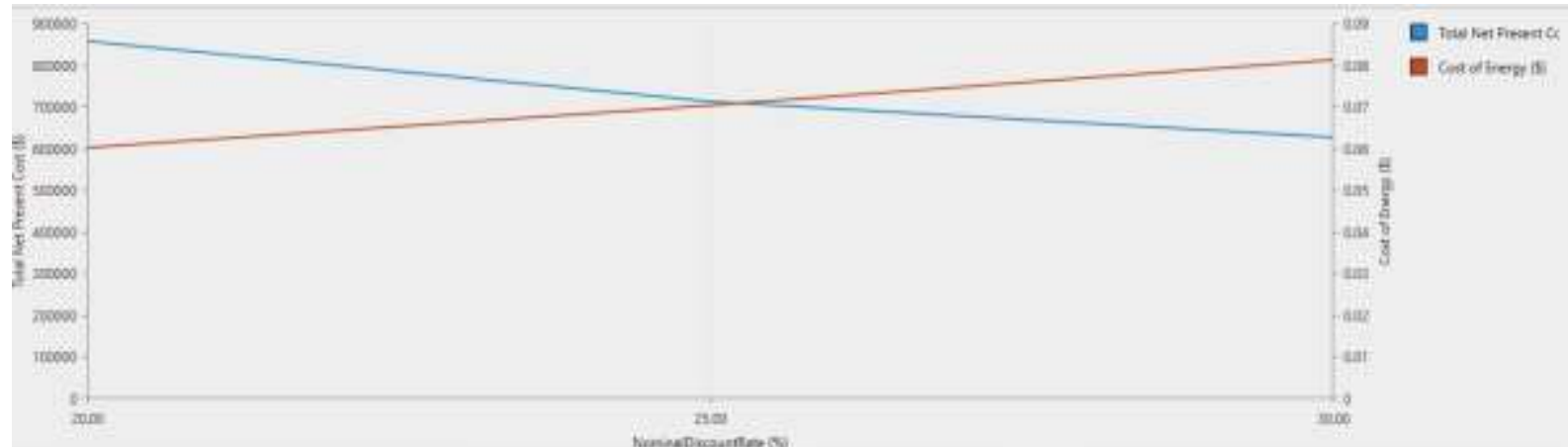

Figure 7: Variation of Nominal Discount rate on COE and TNPC

Source: Authors Construct 


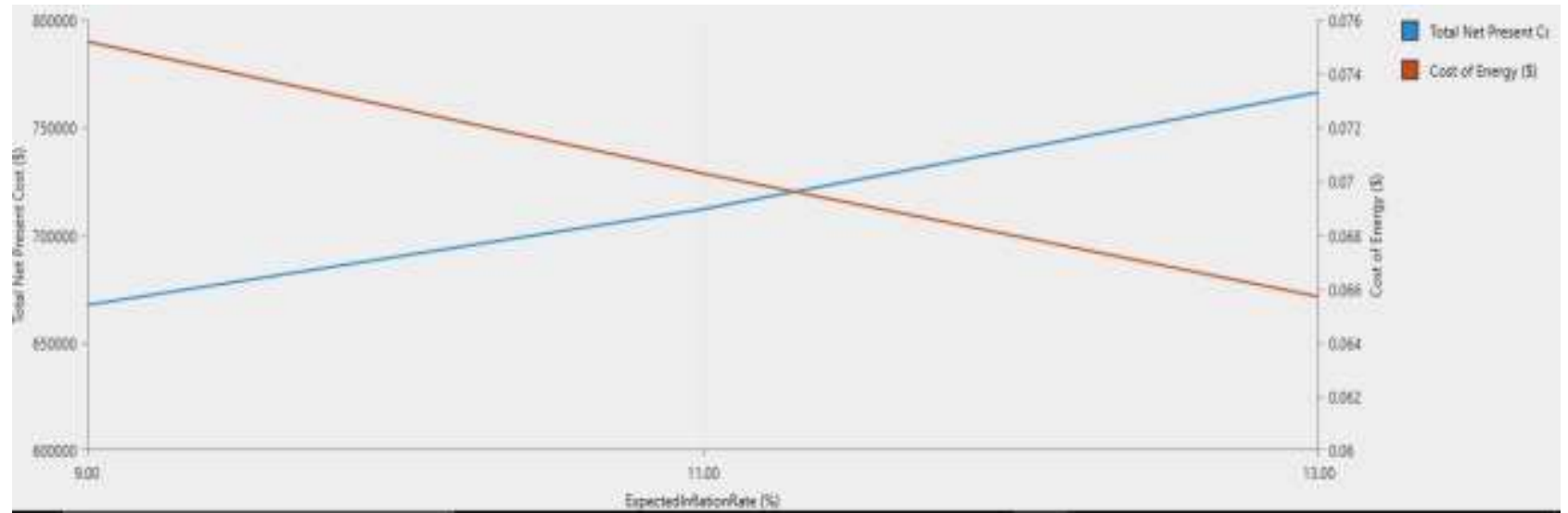

Figure 8: Variation of Inflation Rate on COE and TNPC

Source: Authors Construct

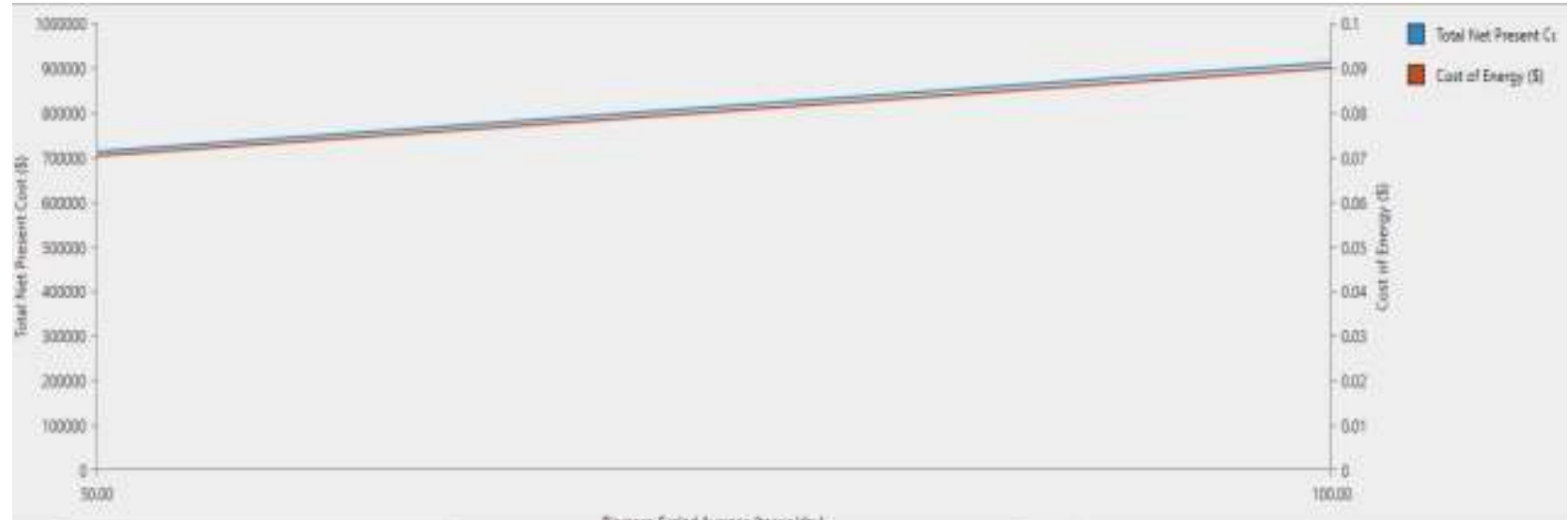

Figure 9: Variation of Rice Husk Generated on COE and TNPC

Source: Authors Construct

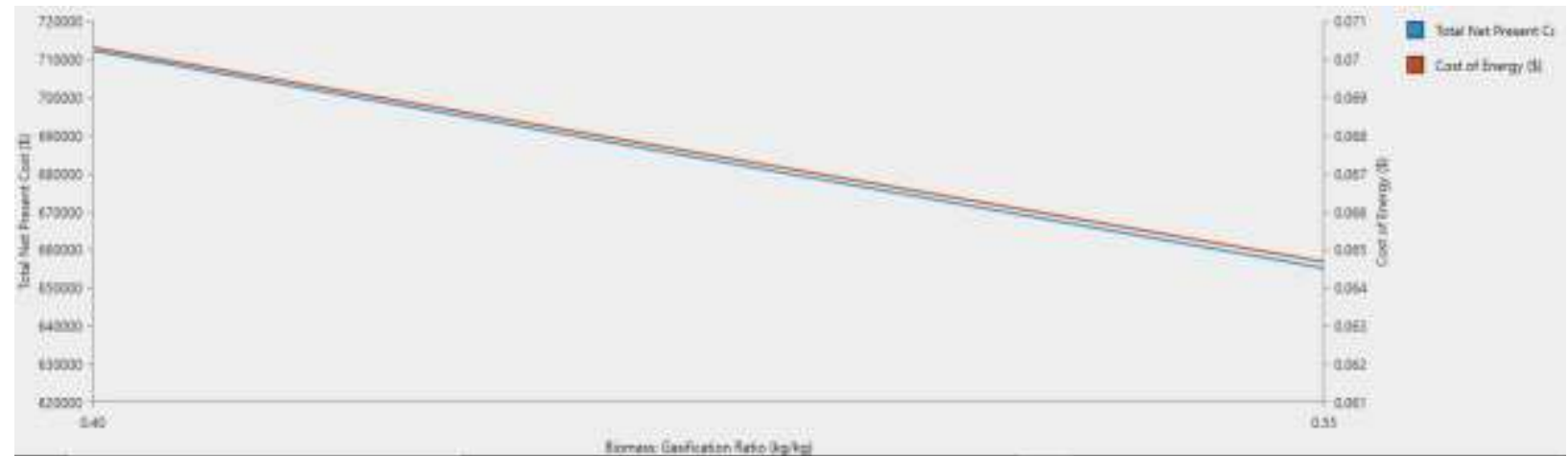

Figure 10. Variation of Gasification Ratio on COE and TNPC

Source: Authors Construct

Conclusion and Recommendations

Kumih et al., 2021: UDSIJD Vol 8(2) 
The study suggests that a biomass system that comprises a $1250 \mathrm{~kW}$ biogas generator is the optimal design for converting rice husk to electricity for the rice mill. The system is technically feasible and economically viable for the Avnash rice mill. Its COE (US\$ $0.0703 \mathrm{kWh}$ ) looks competitive with electricity from the national grid of US\$ $0.190 \mathrm{kWh}$ without consideration of the cost of investment and operation of the gasification system. The addition of cost of investment and operation of the gasification system is expected to increase the COE of the system. It should be considered by stakeholders in decision-making. The average daily consumption of the biomass system is less than the assumed daily generation of rice husk, which suggests that the system would be sustainable. However, the exact daily and monthly rice husk generation would be required to ascertain this assertion, which requires further detailed studies. Sensitivity analysis performed to assess the system behavior also suggests that suitable economic conditions and subsidies by the government in the form of tax waivers or reduced interest on loans would make the technology competitive. The potential of the technology is enormous with exploration for rural/off-grid electrification and the opportunity to manage biodegradable waste in cities and its associated challenges while generating electricity for use. The adequate power supply would increase production hours at the mill. It will also impact the Ghana School Feeding Programme (GSFP) and Planting for Food and Jobs initiatives of the government.

Therefore, the following policy recommendations emanated from the study:

- The research which focused on renewable energy technologies should be given priority by the Government of Ghana in the various institutions to enhance the scientific and technological advancement in the country if the $10 \%$ renewable energy mix is to be achieved.
- To achieve SDG 7, the Government of Ghana should enact laws and formulate policies that would encourage both the public and private sectors to embrace sustainable practices.

Diesel generators seem attractive considering the low initial capital investment; however, operation and maintenance costs are high, with negative environmental impacts. Dwindling fossil fuel reserves and dependence on producing countries' political stability has resulted in a rapid increase in prices, threatening its sustainability.

\section{Acknowledgements}

We are grateful for the immeasurable support and extend our endless thankfulness to all those who have assisted in the study, especially the staff of Avnash company Limited and the School of Engineering - University for Development Studies.

\section{References}

Abedin, R., \& Das, H. S. (2014). Electricity from Rice Husk: A Potential Way to Electrify Rural Bangladesh. 4(3). Acheampong, M., Yu, Q., Ertem, F. C., Coalition, N. E., \& Enomah, L. D. (2019). Is Ghana Ready to Attain Sustainable Development Goal ( SDG) Number 7 ?A Comprehensive Assessment of Its Renewable Energy Potential and Pitfalls. 7. https://doi.org/10.3390/en12030408

Ahlgren, M. M. B. K. S. W. A. D. E. O. (2008). A techno-economic assessment of rice husk-based power generation in the Mekong River Delta of Vietnam. International Journal of Energy Research. Ame-Oko, A. ., Adegboye, B. A. ., \& Tsado, J. (2018). Analytical method to determine the potential of using rice husk for off grid electricity and heat generation. Nigerian Journal of Technology, 37(1), 222. 
https://doi.org/10.4314/njt.v37i1.29

Boafo;, Y. A., Ziem;, R., \& Alhassan, A. (2016). Compound farming system in semi-arid Ghana: a socio-ecological production landscape in decline. In Socioecological production landscapes and seascapes (SEPLS) in Africa (Issue August).

https://www.statsghana.gov.gh/gssmain/st orage/img/marqueeupdater/CPI_AUGUS T_2020_release.pdf

EIA. (2019). International Energy Outlook 2019 with projections to 2050.

ETA-Florence. (2015). Rice husk gasifiers for cost competitive rural electrification $-a$ study in Ghana. BE_sustainable.

Global Petrol Prices. (2020). Ghana gasoline prices, 28-Sep-2020

GlobalPetrolPrices.com.

https://www.globalpetrolprices.com/Ghan a/gasoline_prices/

GSS. (2020). Press Release - Consumer Price Index and Inflation.

IRENA. (2012a). A International Renewable Energy Agency Renewable Energy Technologies: Cost Analysis Series, Biomass for Power Generation. International Renewable Energy Agency, 1(1), 1-20.

IRENA. (2012b). Power Generation Biomass for Wind Power. June.

IRENA. (2014). Supply and Demand Projections (Issue September).

IRENA. (2020a). Global Renewables Outlook: Energy transformation 2050. In International Renewable Energy Agency. https://www.irena.org/publications/2020/ Apr/Global-Renewables-Outlook-2020

IRENA. (2020b). Reaching zero with renewables: Eliminating $\mathrm{CO} 2$ emissions from industry and transport in line with the $1.5^{\circ} \mathrm{C}$ climate goal. 216. https://www.irena.org/publications/2020/S ep/Reaching-Zero-with-Renewables

Islam, M. S., Akhter, R., \& Rahman, M. A. (2018). A thorough investigation on hybrid application of biomass gasifier and PV resources to meet energy needs for a northern rural off-grid region of Bangladesh: A potential solution to replicate in rural off-grid areas or not? Energy, 145, 338-355. https://doi.org/10.1016/j.energy.2017.12.1 25

Jakpa, A., Issahaku;, M., \& Ali, S. (2016).

Physical properties and pyrolysis characteristics of rice husks in different atmosphere. Results in Physics, 6(September), 866-868.

https://doi.org/10.1016/j.rinp.2016.09.011

Kirsanovs, V., Žandeckis, A., \& Rochas, C. (2016). Biomass gasification thermodynamic model including tar and char. 14(4), 1321-1331.

Mhilu, C. F. (2014). Analysis of Energy Characteristics of Rice and Coffee Husks Blends. ISRN Chemical Engineering, 2014, 1-6. https://doi.org/10.1155/2014/196103

Mohiuddin, Obaidullah;, Mohiuddin, A., Obaidullah, M., Ahmed, H., \& AsumaduSarkodie, S. (2016). Electricity production potential and social benefits from rice husk, a case study in Pakistan. Cogent Engineering, 3(1). https://doi.org/10.1080/23311916.2016.11 77156

Mohiuddin, Obaidullah, Mohiuddin, A., Obaidullah, M., \& Asumadu-sarkodie, S. (2016). from rice husk, a case study in Pakistan Electricity production potential and social benefits from rice husk, a case study in Pakistan. Cogent Engineering, 15(1).

https://doi.org/10.1080/23311916.2016.11 77156

Mubarick, I., Sandow, S. A., Addo, E. K., \& Abdul-Fatawu, S. Y. (2020). Meeting the electricity demand with a decentralized autonomous solar PV system using HOMER PRO . A Case Study of AbdulFatawu SeiniYussif. International 
Organization of Scientific Research; Journal of Engineering, 10(3), 41-50. OECD/IEA, \& FAO. (2017). How2Guide for Bioenergy Roadmap Development and Implementation. IEA Publications, 78. http://www.oecd-ilibrary.org/agricultureand-food/biomass-andagriculture_9789264105546-en

Quispe, I., Navia, R., \& Kahhat, R. (2016). Energy potential from rice husk through direct combustion and fast pyrolysis : A review Energy potential from rice husk through direct combustion and fast pyrolysis: A review. Waste Management, 59(October 2017), 200-210. https://doi.org/10.1016/j.wasman.2016.10. 001

Salaudeen, S. A. (2018). Gasification of Plastic Solid Waste and Competitive Technologies. Plastics to Energy, 269293.

Sarkodie, S. A., \& Owusu, P. A. (2016). Feasibility of biomass heating system in Middle East Technical University, Northern Cyprus Campus. Mechanical Engineering Journal, February. https://doi.org/10.1080/23311916.2015.11 34304
Solarte-Toro. (2019). Acid pretreatment of lignocellulose biomass for energy vectors production: A review focused on operational conditions and technoeconomic assessment for bioethanol production. Renewable and Sustainable Energy Reviews, 107, 587-601.

Sue Retka Schill. (2013). Biomass: IEA Task40: Biomass provides 10 percent of global energy use. Biomass Magazine. http://biomassmagazine.com/articles/9444 /iea-task40-biomass-provides-10-percentof-global-energy-use

Twidell, J., \& Tony, W. (2015). Renewable Energy Resources. In Renewable Energy Resources (Third). Routledge Taylor and Francis Group. https://doi.org/10.4324/9781315766416

UNEP. (2008). The Year Book Collection: An overview of our changing environment $(\mathrm{P}$. Harrison (ed.)). Division of Early Warning and Assessment (DEWA).

Yadav, J., Bharat, P., Singh, R., \& Campus, T. (2015). Study on Comparison of Boiler Efficiency Using Husk and Coal as Fuel in Rice Mill. June. https://doi.org/10.18090/samriddhi.v2i2.1 600 